\title{
Potential anti-dengue medicinal plants: a review
}

\author{
Siti Latifah Abd Kadir • Harisun Yaakob • \\ Razauden Mohamed Zulkifli
}

Received: 18 June 2012/Accepted: 12 March 2013/Published online: 17 April 2013

(c) The Author(s) 2013. This article is published with open access at Springerlink.com

\begin{abstract}
Dengue fever causes mortality and morbidity around the world, specifically in the Tropics and subtropic regions, which has been of major concern to governments and the World Health Organization (WHO). As a consequence, the search for new anti-dengue agents from medicinal plants has assumed more urgency than in the past. Medicinal plants have been used widely to treat a variety of vector ailments such as malaria. The demand for plant-based medicines is growing as they are generally considered to be safer, non-toxic and less harmful than synthetic drugs. This article reviews potential anti-dengue activities from plants distributed around the world. Sixtynine studies from 1997 to 2012 describe 31 different species from 24 families that are known for their anti-dengue activities. About ten phytochemicals have been isolated from 11 species, among which are compounds with the potential for development of dengue treatment. Crude extracts and essential oils obtained from 31 species showed a broad activity against Flavivirus. Current studies show that natural products represent a rich potential source of new anti-dengue compounds. Further ethnobotanical
\end{abstract}

\section{S. L. Abd Kadir $(\bowtie)$}

Department of Bioprocess Engineering, Faculty

of Chemical Engineering, Universiti Teknologi Malaysia,

81310 Skudai, Johor, Malaysia

e-mail: slatifah2@live.utm.my

H. Yaakob

Institute of Bioproduct Development, Universiti Teknologi

Malaysia, 81310 Skudai, Johor, Malaysia

e-mail: harisun@ibd.utm.my

R. Mohamed Zulkifli

Department of Biological Sciences, Faculty of Biosciences and Bioengineering, Universiti Teknologi Malaysia,

81310 Skudai, Johor, Malaysia surveys and laboratory investigations are needed established the potential of identified species in contributing to dengue control.

Keywords Dengue fever $\cdot$ Anti-dengue $\cdot$ Medicinal plants · Phytochemical

$\begin{array}{ll}\text { Abbreviations } \\ \text { CC }_{50} & \text { Cytotoxicity concentration } \\ \text { DENV } & \text { Dengue virus } \\ \text { DF } & \text { Dengue fever } \\ \text { DHF } & \text { Dengue hemorrhagic fever } \\ \text { DSS } & \text { Dengue shock syndrome } \\ \text { HPLC } & \text { High performance liquid chromatography } \\ \text { IC }_{50} & \text { Inhibitory concentration } \\ \text { MNTD } & \text { Maximum non-toxic dose } \\ \text { MTT } & \text { 3-(4,5-Dimethylthiazol-2-yl)-2,5- } \\ & \text { diphenyltetrazolium bromide } \\ \text { TCID }_{50} & \text { Median tissue culture infective dose }\end{array}$

\section{Introduction}

Etiology of dengue fever

Dengue fever is caused by the arthropode-borne flavivirus named dengue virus (DENV), transmitted by the Aedes aegypti mosquito [1]. To date, four antigenically related but distinct virus serotypes (DENV-1, 2, 3 and 4) have been identified as belonging to the genus Flavivirus in the Flaviviridae family [2-4]. Infection with one DENV serotype produces only specific antibody against that serotype. When antibody from the first infection is neutralized, secondary infections by other serotypes can cause more 
serious infection [5]. Although DENV-2 is known to be more lethal than other serotypes [6], some studies have revealed that primary infection with DENV-1 or DENV-3 always results in more dangerous disease than infection with DENV-2 or DENV-4 [3, 7]. In recent years, the current dengue epidemic has become a focus of international public health awareness. Unlike malaria, which is more prevalent in remote areas, cases of dengue are distributed mostly in urban and sub-urban areas [8,9]. This has made the epidemic more lethal as an outbreak is difficult to control due to highly populated areas in cities.

Types of DENV infection include mild fever known as dengue fever (DF), which constitutes about $95 \%$ of cases, and a more serious type known as dengue hemorrhagic fever and/or dengue shock syndrome (DHF/DSS, $5 \%$ of cases) $[10,11]$. Recovery from first type of infection provides lifelong immunity; however, it affords only half protection from subsequent viral infection that ultimately results in the risk of DHF. Most dengue infections are characterized by non-specific symptoms including frontal headache, retro-orbital pain, body aches, nausea and vomiting, joint pains, weakness and rash [12, 13].

\section{Epidemiology of dengue fever}

International travel, increasing human population $[14,15]$ and urbanisation create suitable conditions for the mosquito vector $A e$. aegyti, and thus spread the virus to new areas, causing major epidemics [13, 16, 17]. Dengue epidemics are endemic in over 100 countries in Africa, America, Eastern Mediterranean, Southeast Asia and Western Pacific, with Southeast Asia and the Western Pacific being the regions most affected (Fig. 1) [13, 1820]. The first case of DHF was discovered in the 1950s in Thailand and the Philippines [4], where the first two DENV serotypes were identified, followed by the third and fourth serotypes in 1954 [14]. Since then, DHF has recorded major cases resulting in hospitalization and death among children in regions stretching from Asia to Africa and the Pacific [4]. Approximately 2.5 billion people, or half the world's population [14], are now at risk of Dengue, and 50 million infections globally occur annually [4]. Over 100 million cases of DF and at least 500,000 cases of DHF [21] and approximately 18,000 deaths may occur each year [22]. Despite its lethal consequences, the staggering numbers of those affected are increased by the fact that, at present, there is no specific antiviral treatment or vaccine for DF [3]. Early diagnosis and strict hospitalization often save the life of patients with DHF [3, 4, 10]. Efforts to combat the vector have been undertaken by regulatory bodies in an attempt to tackle this problem by awareness campaigns and vector control [16]. Others strategies include the use of plants with bioactive substances that have toxic properties to the vector or insecticidal properties [20]. Clearly, development of antiviral drugs and vaccines is needed in order to support these programs. Moreover, a safe, low-cost, and effective vaccine to control DENV woudl be needed, especially in the most affected countries, which are poor $[2,16]$. Therefore, the search of highly selective but non-toxic antiviral compounds is urgently needed in view of the spread of dengue disease throughout the world [23].

\section{Global distribution of dengue fever}

Guangdong province in China has become a major area with reported cases of dengue [24]. From 2000 to 2005, a total of 2,496 cases of dengue were recorded. The epidemic peaked in 2002. In Northern Thailand there were 13,915, 11,092, 6,147, 6,992 and 6,914 DF cases reported during the period 2002-2006 [25]. Outbreaks of DF and DHF have been reported in India over the past four decades [26]. From 2001 to 2002, Delhi recorded a decline in cases of
Fig. 1 Green Countries or areas at risk of dengue, 2012. The contour lines of the January and July isotherms indicate the potential geographical limits of the northern and southern hemispheres for year-round survival of Aedes aegypti, the principal mosquito vector of dengue viruses. This copyrighted map is reproduced with acknowledgment to the World Health Organization (WHO)

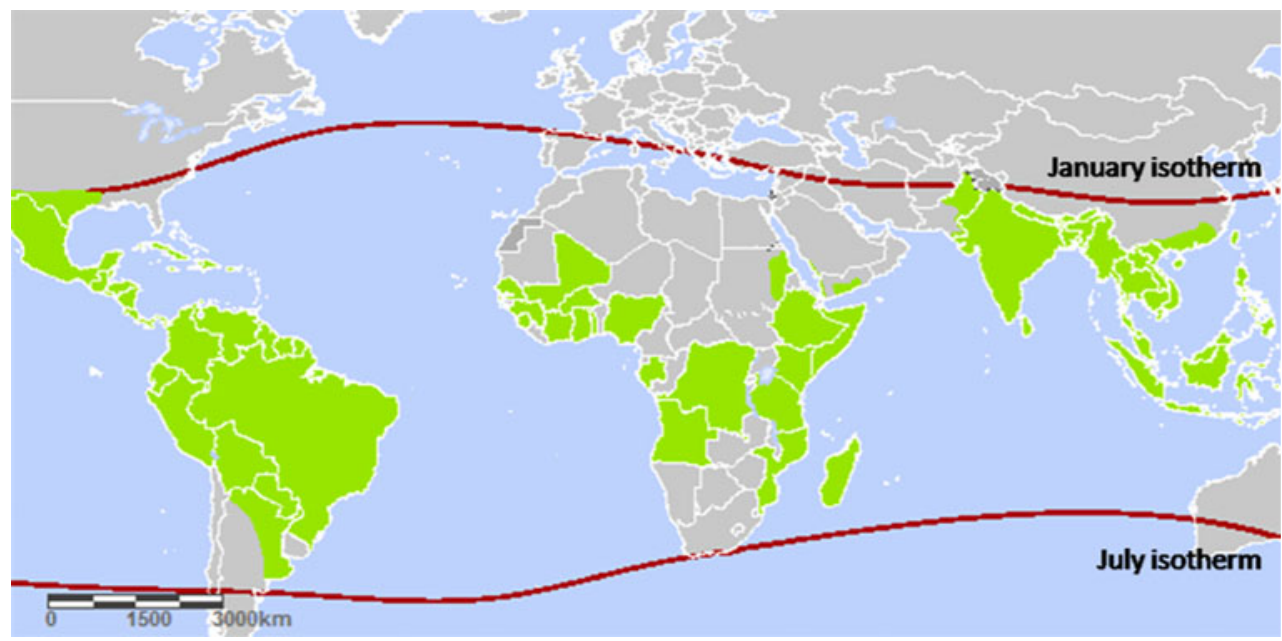


DF/DHF, with a total of 1,380 cases, but deaths decreasing from 53 cases (2001) to 35 cases (2002). However, outbreaks of DF cases rose sharply in 2003, with a total of 12,754 cases and 215 deaths.

\section{Dengue fever in Malaysia}

In Malaysia, with a population of 27.7 million and a population density of 84 per $\mathrm{km}^{2}$ [27], outbreaks of dengue cases are endemic, with increasing cases of dengue over the past two decades. The first case was documented in 1902 [16, 28, 29]. During the period 1973-1982, 12,077 dengue cases were reported, with a fatality rate of $3.38 \%$. The number of cases rose in following decade of 1983-1992 with 26,361 cases; however, the fatality rate was down to $0.55 \%$ [28]. In 2004 and 2005, dengue was reported with 13,558 and 15,862 incidence rate, respectively, per 100,000 population. With an increase of $16.99 \%$ of cases, a total of 107 deaths were recorded in 2005 compared to 102 cases in 2004 [29]. According to Health Facts 2006 (Ministry of Health Malaysia), the incidence rates of DF and DHF were 64.37 and 4.10 per 100,000 population, respectively, with mortality rate of 0.01 (DF) and 0.25 (DHF) [30]. In a press statement, the Director General of Health Malaysia, reported a total of 545 cases and four deaths in 5 weeks in 2012 as the highest increase of dengue cases and deaths, with an increase of 57 cases $(12 \%)$ compared to 488 cases with two deaths the previous week [31]. In the period 2009-2011, the number of dengue cases decreased to 21,602 cases with the peak appearing in 2010 (Fig. 2) [32-36].

Since early human civilization, plants have been a source of traditional medicine, and demands for herbal and natural product have recently increased. About 70-95 \% people worldwide now rely on traditional herbs as the primary treatment for various diseases [37]. It is estimated that about $25 \%$ of modern drugs, including antiviral agent, originate from natural products [38] with over $60 \%$ of anti-cancer compounds and $75 \%$ of infectious disease

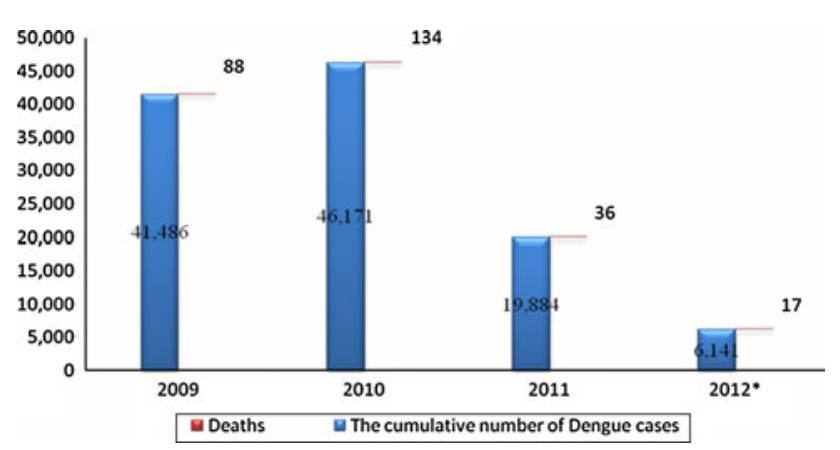

Fig. 2 Reported dengue cases in the years 2009-2012 in Malaysia [32-36]. *Data up to 24 March 2012 drugs being derived from natural ingredients, which are more acceptable, less toxic and less expensive than synthetic drugs [39, 40]. Several studies have reported potential antiviral agents from plants in the form of crude extracts, essential oils or purified compounds [41, 42]. Recent studies have reported the potential of some flavonoid compounds as antivirals against DENV-2 [40, 43].

Pathophysiology of dengue fever

Dengue infection is caused by bites of the female Ae. aegypti mosquito carrying Flavivirus. After a person is bitten, the virus incubation period varies between 3 and 14 days [3, 18], after which the person may experience early symptoms such as fever, headache, rash, nausea, and joint and musculoskeletal pain [3, 13]. This classic DF records temperatures between 39 and $40{ }^{\circ} \mathrm{C}$ and usually lasts 5-7 days [6]. During this period, the virus may get into the peripheral bloodstream and, if left untreated, can damage blood vessels and lymph nodes resulting in DHF with symptoms such as bleeding from the nose, gums or under the skin [18]. DHF patients also have difficulty in breathing and severe development can lead to DSS. DSS can result in death if proper treatment is not provided.

Aedes mosquitoes are small and black with white markings on the body and legs. Female mosquitoes need blood from biting humans or animals to produce live eggs. It takes 2-3 days for egg development. The principal vector of dengue (Ae. aegypti) has adapted well to the urban environment $[14,17]$ and always breeds in stagnant containers. Eggs need moist conditions, and mature in 24-72 h [44]. Mosquito bites are the only route of DENV spread. The transmission of DENV is often from human to human through domestic mosquitoes [6]. An outbreak starts after a mosquito sucks the blood of a patient with DF/ DHF (Fig. 3) [44]. After being transmitted to a new human host by infected mosquitoes, the virus replicates in the lymph nodes and spreads through the lymph and blood to other tissues [6]. To identify a potential antiviral treatment

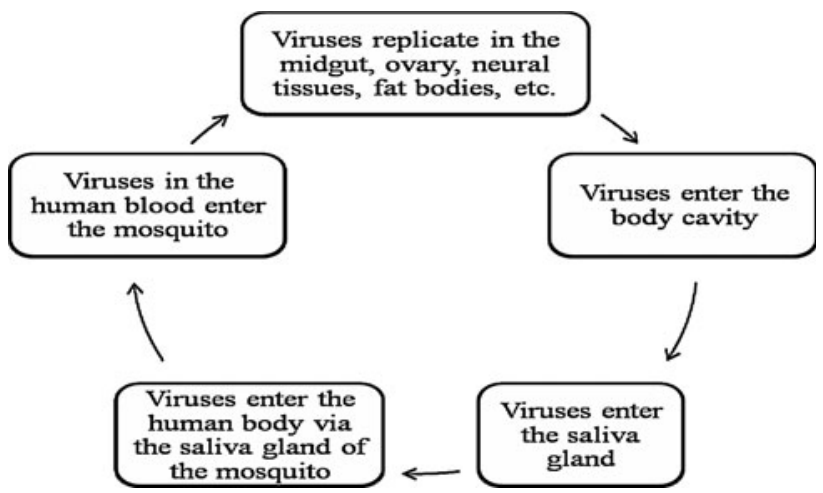

Fig. 3 Dengue virus transmission cycle 


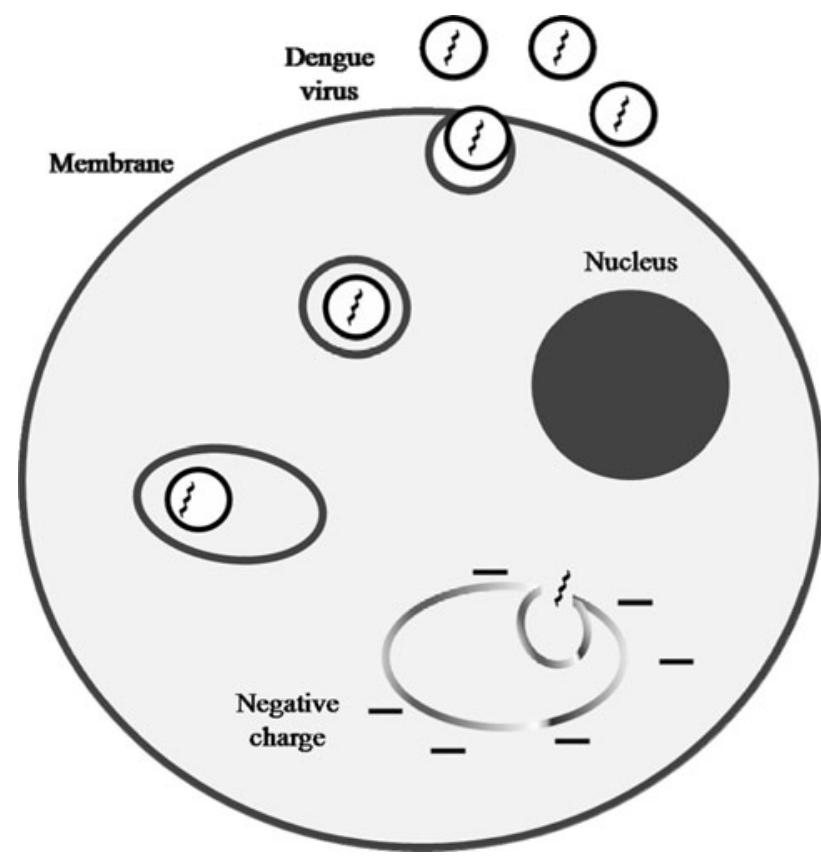

Fig. 4 Dengue virus infection cycle in cells

for DENV, it is necessary to understand the life cycle of the virus. The dengue virion is a small particle with a lipoprotein envelope and an icosahedral nucleocapsid containing a positive single-stranded RNA genome [6, 12, 23]. Virus infection of the cell begins with binding to the host cell surface. It enters the cell by receptor-mediated endocytosis [15], with the cell membrane forming a sac-like structure known as an endosome. In the endosome, the virus penetrates deep into the cell until the endosome membrane acquires a negative charge, which allows it to fuse with the endosomal membrane to open a port for release of genetic material. At this point, the virus in the cell fluid starts to reproduce. Changes in the acidity of the secretory pathway during this viral journey travel play an important role in its maturation (Fig. 4).

Possible mechanisms and pathways in the treatment of dengue

There are currently no specific treatments for dengue fever [22]. Only standard treatment for management of fever is given, i.e., nursing care, fluid balance, electrolytes and blood clotting parameters [18]. Patients with dengue fever will be treated symptomatically, for example, sponging, acetaminophen [9], bed rest and oral rehydration therapy, and if signs of dehydration or bleeding occur the patients are usually hospitalized [6]. Aspirin should be avoided because it may cause bleeding [9]. Platelet count and Hematocrit should be measured daily from the suspected day of illness until 1-2 days after defervescence [9]. Current prevention of dengue by potential dengue vaccine and vector control is highly cost effective [22, 45]. In addition, mosquito control programs are the most important preventive method [6]. However, these are difficult to implement and maintain [39]. Development of a vaccine for dengue is difficult since there are four closely related, but antigenically distinct, serotypes of the virus that can cause disease $[6,46]$. Infection by one serotype does not ensure protection of the patient from infection by the other three serotypes [15]. Therefore, if vaccine were produced for only one or two serotypes, the other serotypes would increase the risk of more serious illness [47]. Ribavirin has shown significant in vivo activity against RNA viruses; however, it exhibited only very weak activity against Flaviviruses [21]. A possible strategy in the treatment of dengue is to use chimeric tetravalent vaccines that show high neutralizing antibody against all dengue serotypes [9, 15]. Studies on the development of tetravalent vaccines are ongoing in Thailand and these should be available in the near future [6]. In addition, recombinant vaccines against capsid, premembrane and envelope genes of DENV-1, -2 and -3 inserted into a copy of a DNA infectious clone of DENV-2 are being developed and are currently undergoing clinical trials [48].

\section{Plants traditionally used to treat dengue}

According to a World Health Organization (WHO) fact sheet dated December 2008, $80 \%$ of the population in some Asian and African countries depends on traditional medicine as their primary health care due to economic and geographical constraints [49]. Natural products have become the main source of test material in the development of antiviral drugs based on traditional medical practices [50]. Traditional medicines are based on knowledge, experience and practices based on indigenous cultural beliefs and knowledge, and are used to maintain health, prevent, treat and diagnose physical or mental illness [49]. Traditional medicinal plants have been reported to have antiviral activity $[49,51,52]$ and some have been used to treat viral infections in animals and humans.

To date, 31 different species have been found to have the potential to treat dengue; some of these have not yet been investigated scientifically (as indicated in Table 1). In the Philippines, Euphorbia hirta, known locally as "tawatawa", is used in folk medicine to cure dengue fever by people in rural areas [53]. Practitioners of traditional medicines believe that decoction of tawa-tawa leaves can reverse viral infection and prevent the fever from moving into critical stages, although there are no scientific studies proving its effectiveness [54]. Sometimes, tawa-tawa is prepared together with papaya leaves since papaya leaf extract has a function as an antibiotic to cure fever. While papaya leaf extract kills the bacterial infection that caused 


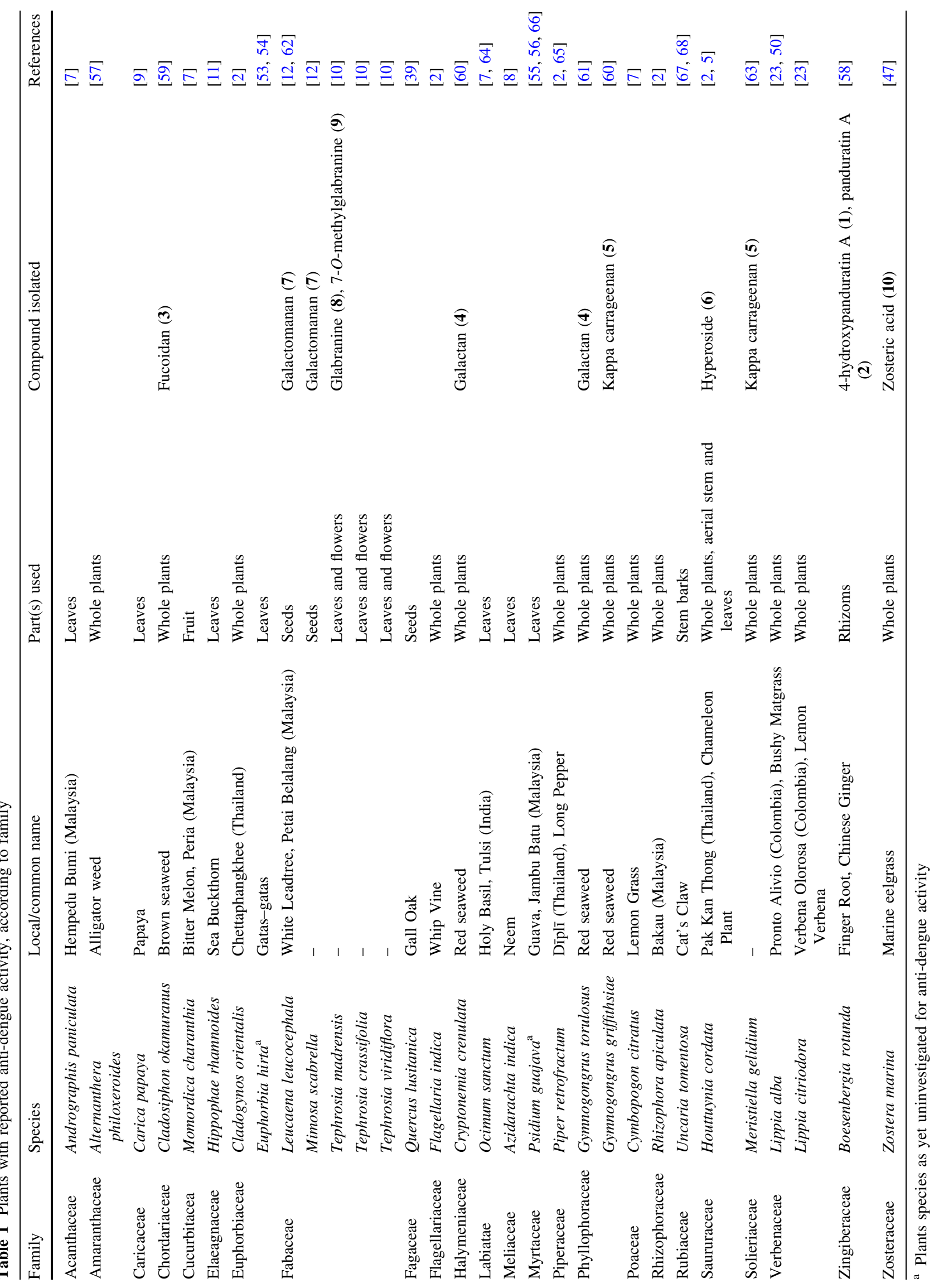


the fever, tawa-tawa extract prevents bleeding. In addition, unpublished research has found that Psidium guava leaves are a good way to increase platelets, thus helping to avoid bleeding [55]. A water decoction of guava leaves contains quercetin, which acts to inhibit the formation of enzyme mRNA in the virus [56].

\section{Overview of studies on plant species used as anti-dengue}

The use of herbal-based medicine and medicinal plants to treat many diseases is growing worldwide as they has few or no adverse effects. The following sections describe some species of medicinal plants from various families that have been investigated for anti-dengue activity (Table 1). In addition, we describe species used as traditional treatment for dengue together with their isolated compound.

\section{Alternanthera philoxeroides}

Alternanthera philoxeroides belongs to family Amaranthaceae. A. philoxeroides is also called "Alligator Weed", and is an immersed aquatic plant. It originated from South America but is currently invading Australia.

The effect of A. philoxeroides extracts against dengue virus was investigated in vitro [57]. An MTT assay was carried out to determine the cytotoxicity of A. philoxeroides on $\mathrm{C} 6 / 36$ cell lines. Coumarin extract of A. philoxeroides showed lowest toxicity on cells $\left(\mathrm{TD}_{50}=535.91\right)$, whereas a petroleum ether extract of A. philoxeroides had the strongest inhibitory effect on dengue virus $\left(\mathrm{ED}_{50}=47.43\right)$.

\section{Andrographis paniculata}

Andrographis paniculata belongs to family Acanthaceae. It is an erect annual herb native to India and Sri Lanka and cultivated widely in Southern and Southeastern Asia. In Malaysia, it is called "Hempedu Bumi", which has a bitter taste.

The maximum nontoxic dose (MNTD) of methanolic extract of A. paniculata against Vero E6 cells in vitro was investigated [7]. A. paniculata recorded the maximal dose, which was not toxic to cells at $0.050^{-1}$. The methanolic extract of $A$. paniculata showed the highest antiviral inhibitory effect on DENV-1 by antiviral assay based on cytopathic effects.

\section{Azidarachta indica}

Azidarachta indica belongs to the family Meliaceae. It is fast-growing tree with a final height in the range of
15-20 m. It is native to India and Pakistan and grows throughout tropical and semi-tropical regions.

The in vitro and in vivo inhibitory potential of aqueous extract of Azidarachta indica (neem) leaves on the replication of DENV-2 was evaluated [8]. Cytotoxicity studies were carried out to determine the MNTD in a virus inhibition assay. The aqueous extract of neem leaves (NL) completely inhibited 100-10,000 tissue culture infective dose $(\text { TCID })_{50}$ of virus as indicated by the absence of cytopathic effects at its maximum non-toxic concentration of $1.897 \mathrm{mg} \mathrm{mL}^{-1}$. An in vivo study on the inhibitory effects on virus of NL aqueous extract in day-old suckling mice was carried out by intracerebral inoculation. It was shown that the aqueous extract inhibited the virus at nontoxic doses in the range of $120-30 \mathrm{mg} \mathrm{mL}^{-1}$ as indicated by the absence of 511-bp dengue group specific amplicons upon RT-PCR.

\section{Boesenbergia rotunda}

Boesenbergia rotunda belongs to family Zingiberaceae. It is a medicinal and culinary herb known as Chinese ginger. It is found throughout China and Southeast Asia.

The activity of some compounds extracted from $B$. rotunda for the inhibition of dengue virus protease has been tested on DENV-2 [58]. The cyclohexenyl chalcone derivatives of $B$. rotunda, 4-hydroxypanduratin A (1) and panduratin A (2) showed good competitive inhibitory activities towards DENV-2 NS3 protease with $K_{\mathrm{i}}$ values of $21 \mu \mathrm{M}$ and $25 \mu \mathrm{M}$, respectively. The small value of $K_{\mathrm{i}}$ shows the potential of 4-hydroxypanduratin $\mathrm{A}$ to inhibit DENV-2 NS3 protease in vitro.

\section{Carica papaya}

Carica papaya belongs to family Caricaceae. It is an erect, fast-growing and unbranched tree or shrub indigenous to Central America and cultivated in Mexico and most tropical countries for its edible fruits.

C. papaya leaf has been used traditionally in the treatment of DF [55]. The leaf has been investigated for its potential against DF. The aqueous extract of leaves of this plant exhibited potential activity against DF by increasing the platelet (PLT) count, white blood cells (WBC) and neutrophils (NEUT) in blood samples of a 45-year-old patient bitten by carrier mosquitoes [9]. After 5 days of oral administration of $25 \mathrm{~mL}$ aqueous extract of $C$. papaya leaves to the patient twice daily, the PLT count increased from $55 \times 10^{3} / \mu \mathrm{L}$ to $168 \times 10^{3} / \mu \mathrm{L}, \mathrm{WBC}$ from $3.7 \times 10^{3} /$ $\mu \mathrm{L}$ to $7.710^{3} / \mu \mathrm{L}$ and NEUT from 46.0 to $78.3 \%$. Increased platelets could lead to reduced bleeding, thus avoiding progression to the severe illness of DHF. 


\section{Cladogynos orientalis}

Cladogynos orientalis belongs to family Euphorbiaceae. It is a white-stellate-hairy shrub about $2 \mathrm{~m}$ high found in Southeast Asia, Malaysia and Thailand.

The in vitro activity of Cladogynos orientalis - a Thai medicinal plant-against dengue virus was evaluated [2]. The dichloromethane ethanol extract of $C$. orientalis was tested for anti-dengue activities against DENV-2 in Vero cells by the MTT method. The results showed that the ethanol extract of $C$. orientalis at a concentration of $12.5 \mu \mathrm{g} \mathrm{mL}^{-1}$ exhibited inhibitory activity on DENV-2 with $34.85 \%$. In addition, $C$. orientalis at a concentration of $100 \mu \mathrm{g} \mathrm{mL}^{-1}$ exhibited an inactivated viral particle activity of $2.9 \%$.

\section{Cladosiphon okamuranus}

Cladosiphon okamuranus belongs to family Chordariaceae. It is a brown seaweed found naturally in Okinawa, Japan.

A sulfated polysaccharide named fucoidan (3) from Cladosiphon okamuranus was found to potentially inhibit DENV-2 infection [59]. The virus infection was tested in BHK-21 cells in a focus-forming assay. Fucoidan reduced infectivity by $20 \%$ at $10 \mu \mathrm{g} \mathrm{mL}^{-1}$ as compared with untreated cells. However, a carboxy-reduced fucoidan in which glucuronic acid was converted to glucose attenuated the inhibitory activity on DENV2 infection.

\section{Cryptonemia crenulata}

Cryptonemia crenulata belongs to family Halymeniaceae. It is a marine species found throughout the Atlantic Islands, North America, Caribbean Islands, Western Atlantic, South America, Africa, Indian Ocean Islands, Southeast Asia and Pacific Islands.

The sulfated polysaccharides from Cryptonemia crenulata, i.e., galactan (4), were selective inhibitors of DENV-2 multiplication in Vero cells with $\mathrm{IC}_{50}$ values of $1.0 \mu \mathrm{g} \mathrm{mL}^{-1}$, where the $\mathrm{IC}_{50}$ values for the reference polysaccharides heparin and DS8000 were 1.9 and $0.9 \mu \mathrm{g} \mathrm{mL}^{-1}$, respectively [60]. However, the compound has lower antiviral effect against DENV-3 and DENV-4, and was totally inactive against DENV-1. The inhibitory effect of C2S-3 against DENV-2 was slightly higher when treatment was by adsorption $\left(\mathrm{EC}_{50}=2.5 \pm 0.1 \mu \mathrm{g} \mathrm{mL}^{-1}\right.$ ) with respect to treatment only during internalization $\left(\mathrm{EC}_{50}=5.5 \pm 0.7 \mu \mathrm{g} \mathrm{mL}^{-1}\right)$ [1]. Thus, the inhibitory effect was increased when $\mathrm{C} 2 \mathrm{~S}-3$ was included at both stages of adsorption and internalization.
Cymbopogon citratus

Cymbopogon citratus belongs to family Poaceae. It is a grass species known as lemon grass and is a tropical plant from Southeast Asia.

The antiviral activity of Cymbopogon citratus was determined based on cytopathic effects shown by the degree of inhibition of DENV-1 infected Vero E6 cells [7]. The methanolic extract of $C$. citratus showed a slight inhibition effect on DENV-1. This result was further confirmed with an inhibition assay by the MTT method. However, C. citrates showed no significant inhibition. Moreover, C. citratus showed the lowest of MNTD at concentration of $0.001 \mathrm{mg} \mathrm{mL}^{-1}$. C. citratus was found to be quite a cytotoxic plant as it showed maximum cytotoxicity at $0.075 \mathrm{mg} \mathrm{mL}^{-1}$.

\section{Euphorbia hirta}

Euphorbia hirta belongs to family Euphorbiaceae. It is a common weed in garden beds, garden paths and wastelands and is found throughout Java, Sunda, Sumatra, Peninsular Malaysia, the Philippines and Vietnam.

The water decoction of leaves from Euphorbia hirta, locally known as gatas-gatas, is used in the Philippines as a folk medicine to treat DF [54]. Internal haemorrhaging will stop and dengue fever will be cured after $24 \mathrm{~h}$. However, the mechanism of action is still unknown and the antiviral properties and its ability to increase blood platelets are currently investigated. The tea obtained from boiled leaves of E. hirta is used to cure DF [53].

\section{Flagellaria indica}

Flagellaria indica belongs to family Flagellariaceae. It is robust perennial climber that grows in many of the tropical and subtropical regions of the Old World, India, Southeast Asia, Polynesia and Australia.

Flagellaria indica was investigated for its anti-dengue properties in Vero cells [2]. The antiviral assay results show that $45.52 \%$ inhibition of DENV-2 was observed in vitro in the presence of $12.5 \mu \mathrm{g} \mathrm{mL}^{-1}$ of ethanol extract of the plant. By conducting MTT assays, the cytotoxicity of $F$. indica was determined. The $\mathrm{CC}_{50}$ of ethanol extract of $F$. indica were $312 \mu \mathrm{g} \mathrm{mL}^{-1}$. Thus, this study indicates that $F$. indica has a significant potential effect on DENV.

\section{Gymnogongrus griffithsiae}

Gymnogongrus griffithsiae belongs to family Phyllophoraceae. It is a red seaweed found in Ireland, Europe, Atlantic Islands, North America, South America, Caribbean Islands, 
Africa, Southwest and Southeast Asia and Australia and New Zealand.

The inhibitory properties against DENV-2 of the sulfated polysaccharide from Gymnogongrus griffithsiae, kappa carrageenan (5) was evaluated in Vero cells [60]. The compound effectively inhibits DENV-2 multiplication at the $\mathrm{IC}_{50}$ value of $0.9 \mu \mathrm{g} \mathrm{mL}{ }^{-1}$, which is the same as the $\mathrm{IC}_{50}$ value for the commercial polysaccharides DS8000. However, the compound has lower antiviral effect against DENV-3 and DENV-4, and was totally inactive against DENV-1.

\section{Gymnogongrus torulosus}

Gymnogongrus torulosus belongs to family Phyllophoraceae. It is a red seaweed found in Australia and New Zealand.

Gymnogongrus torulosus was investigated for its in vitro antiviral properties against DENV-2 in Vero cells [61]. Galactan (4) extracted from this plant was active against DENV-2, with $\mathrm{IC}_{50}$ values in the range of $0.19-1.7 \mu \mathrm{g} \mathrm{mL}^{-1}$.

\section{Hippophae rhamnoides}

Hippophae rhamnoides belongs to family Elaeagnaceae. It is a deciduous shrub occurring throughout Europe including Britain, from Norway south and east to Spain, and in Asia to Japan and the Himalayas.

The anti-dengue activity of extracts of Hippophae rhamnoides leaves was investigated against dengue virus type-2 (DENV-2) in infected blood-derived human macrophages [11]. The findings showed that cells treated with $H$. rhamnoides leaf extracts was able to maintain cell viability of dengue-infected cells on par with Ribavirin, a commercial anti-viral drug along with a decrease and increase in TNF- $\alpha$ and IFN- $\gamma$, respectively. Moreover, $H$. rhamnoides leaf extract proved its anti-dengue activity as indicated by a decrease in plaque numbers after the treatment of infected cells.

\section{Houttuynia cordata}

Houttuynia cordata belongs to family Saururaceae. It is herbaceous perennial flowering plants growing between 20 and $80 \mathrm{~cm}$, and is native to Japan, Korea, Southern China and Southeast Asia.

Ethanol extract from Houttuynia cordata revealed an anti-dengue activity with $35.99 \%$ inhibition against DENV-2 in Vero cells at a concentration of $1.56 \mu \mathrm{g} \mathrm{mL}^{-1}$ [2]. Aqueous extract of $H$. cordata showed effective inhibitory action against DENV-2 through direct inactivation of viral particles before infection of the cells [5]. A concentration of $100 \mu \mathrm{g} \mathrm{mL}^{-1}$ also effectively protects the cells from viral entry and inhibits virus activities after adsorption. HPLC analysis of $H$. cordata extract indicated that hyperoside (6) was the predominant bioactive compound, and was likely to play a role in this inhibition.

\section{Leucaena leucocephala}

Leucaena leucocephala belongs to family Fabaceae. It is a species of Mimosoid tree indigenous throughout Southern Mexico and Northern Central America and the West Indies from the Bahamas and Cuba to Trinidad and Tobago.

Galactomannans (7) extracted from seeds of Leucaena leucocephala have demonstrated activity against yellow fever virus (YFV) and DENV-1 in vitro and in vivo [12]. Galactomannans are polysaccharides consisting of a mannose backbone with galactose side groups, more specifically their structure consists of a main chain of $(1 \rightarrow 4)$-linked $\beta$-D-mannopyranosyl units substituted by $\alpha$-D-galactopyranosyl units [62]. L. leucocephala show protection against death in $96.5 \%$ of YFV-infected mice. In vitro experiments with DENV-1 in C6/36 cell culture assays showed that the concentration producing a 100 -fold decrease in virus titer of DENV-1 was $37 \mathrm{mg} \mathrm{L}^{-1}$.

\section{Lippia alba and Lippia citriodora}

Lippia alba and Lippia citriodora belong to family Verbenaceae. They are flowering plants native to Southern Texas, Mexico, the Caribbean, Central and South America.

Essential oils from Lippia alba and Lippia citriodora showed a considerable inhibitory effect on dengue virus serotype replication in Vero cells [23]. A $50 \%$ reduction in virus plaque number values was found with $L$. alba oil at between $0.4-32.6 \mu \mathrm{g} \mathrm{mL}^{-1}$ whereas for L. citriodora oil, the $\mathrm{IC}_{50}$ values were between 1.9 and $33.7 \mu \mathrm{g} \mathrm{mL}^{-1}$. $L$. alba essential oil was more effective against DENV-2 than other serotypes, while for L. citriodora essential oil, the virucidal action against DENV-1, 2 and 3 were similar but lower than against DENV-4. Essential oil of L. alba was observed to produce a $100 \%$ reduction of YFV yield at $100 \mu \mathrm{g} \mathrm{mL}^{-1}[50]$.

\section{Meristiella gelidium}

Meristiella gelidium belongs to family Solieriaceae. It is a marine species found in Atlantic Islands, North America, Caribbean Islands and South America.

The antiviral activity of kappa carragenan (5) in Meristiella gelidium was evaluated against DENV-2 [63]. The $\mathrm{IC}_{50}$ of carragenans isolated from $M$. gelidium was in the range of $0.14-1.6 \mu \mathrm{g} \mathrm{mL}^{-1}$. The results show that the extract and the fraction derived from $M$. gelidium were 
more effective inhibitors of DENV-2 when compared with reference polysaccharides (heparin and DS 8000).

\section{Mimosa scabrella}

Mimosa scabrella belongs to family Fabaceae. It is a fastgrowing, 15-20 m high and up to $50 \mathrm{~cm}$ diameter tree native to the cool, subtropical plateaus of Southeastern Brazil.

Galactomannans (7) extracted from seeds of Mimosa scabrella have demonstrated activity against YFV and DENV-1 in vitro and in vivo [12]. M. scabrella showed protection against death in $87.7 \%$ of YFV-infected mice. In vitro experiments with DENV-1 in C6/36 cell culture assays showed that a concentration of $347 \mathrm{mg} \mathrm{L}^{-1}$ produced a 100 -fold decrease in virus titer of DENV-1.

\section{Momordica charantia}

Momordica charantia belongs to family Cucurbitaceae. It is also known as bitter melon or peria (Malaysia), a tropical and subtropical vine found throughout Asia, Africa and the Caribbean.

The MNTD of the methanolic extract of Momordica charantia against Vero E6 cells was investigated in vitro [7]. M. charantia recorded a maximal dose that was not toxic to cells of $0.20 \mathrm{mg} \mathrm{mL}^{-1}$. The methanolic extract of M. charantia showed inhibitory effect on DENV-1 by antiviral assay based on cytopathic effects.

\section{Ocimum sanctum}

Ocimum sanctum belongs to family Labiatae. It is an aromatic herb and shrub native to the tropical regions of Asia and the Americas.

Tea, which is traditionally prepared by using Ocimum sanctum boiled leaves, acts as a preventive medicament against DF [64]. The MNTD of methanolic extract of $O$. sanctum against Vero E6 cells in vitro was investigated [7]. However, no significant difference in MNTD for $O$. sanctum was recorded. The methanolic extract of $O$. sanctum showed a slight inhibitory effect on DENV-1 based on cytopathic effects.

\section{Piper retrofractum}

Piper retrofractum belongs to family Piperaceae. It is a flowering vine native to Southeast Asia and cultivated in Indonesia and Thailand mostly for its fruit.

In vitro anti-dengue activity of Piper retrofractum in Vero cells was investigated [2]. The inhibitory activity against DENV-2 infected cells was determined on dichloromethane ethanol extract by the MTT method. The ethanol extract of $P$. retrofractum exhibited an inactivated viral particle activity or $84.93 \%$ at a concentration of $100 \mu \mathrm{g} \mathrm{mL}^{-1}$. Previous study has shown that an aqueous extract of long pepper, $P$. retrofractum, gives the highest level of activity against mosquito larvae [65].

\section{Psidium guajava}

Psidium guajava belongs to family Myrtaceae. It is an evergreen shrub or small tree indigenous to Mexico, the Caribbean and Central and South America. It is cultivated widely in tropical and subtropical regions around the world.

Psidium guajava leaf extract has been tested in vitro and showed to inhibit the growth of dengue virus [66]. Water boiled with guava leaves was used to avoid bleeding in DHF, and increased platelet counts to $100.000 / \mathrm{mm}^{3}$ within a period of approximately $16 \mathrm{~h} \mathrm{[56].} \mathrm{P.} \mathrm{guajava} \mathrm{ripe} \mathrm{fruit}$ or juice has healing properties in cases of DF by improving the declining levels of platelets [55].

\section{Quercus lusitanica}

Quercus lusitanica belongs to family Fagaceae. It is a species of oak native to Morocco, Portugal and Spain.

Quercus lusitanica extract was found to have a good inhibitory effect on the replication of DENV-2 in C6/36 cells [39]. The methanol extract of the seeds completely inhibited (10-1,000 fold) the TCID 50 of virus at its maximum non-toxic concentration of $0.25 \mathrm{mg} \mathrm{mL}^{-1}$ as indicated by the absence of cytopathic effects. A low dose of $Q$. lusitanica $\left(0.032 \mathrm{mg} \mathrm{mL}^{-1}\right)$ showed $100 \%$ inhibition with 10 TCID $_{50}$ of virus. Proteomics techniqueswere used to demonstrate that the effect of $Q$. lusitanica was to downregulate NS1 protein expression in infected c6/36 cells after treatment with the extract.

\section{Rhizophora apiculata}

Rhizophora apiculata belongs to family Rhizophoraceae. It is a mangrove tree up to $20 \mathrm{~m}$ tall that grows in Australia (Queensland and Northern Territory), Guam, India, Indonesia, Malaysia, Micronesia, New Caledonia, Papua New Guinea, the Philippines, Singapore, the Solomon Islands, Sri Lanka, Taiwan, Maldives, Thailand and Vietnam.

Anti-dengue properties of the ethanolic extract of $R h i$ zophora apiculata in DENV-2 in Vero cells have been reported [2]. $R$. apiculata exhibited inhibitory activity and an inactivated viral particle activity of $56.14 \%$ and $41.5 \%$ at concentrations of 12.5 and $100 \mu \mathrm{g} \mathrm{mL}^{-1}$, respectively. 
Table 2 Some medicinal plants tested for their anti-dengue activity

\begin{tabular}{|c|c|c|c|c|c|}
\hline Family & Species & Part(s) used & Extracts tested & Stage of validation & References \\
\hline Amaranthaceae & $\begin{array}{l}\text { Alternanthera } \\
\text { philoxeroides }\end{array}$ & Whole plants & $\begin{array}{l}\text { Petroleum ether, ethyl } \\
\text { ether, ethyl acetate and } \\
\text { coumarin extract }\end{array}$ & In vitro & {$[57]$} \\
\hline Chordariaceae & Cladosiphon okamuranus & Whole plants & Ethanol extract & In vitro & [59] \\
\hline Euphorbiaceae & Cladogynos orientalis & Whole plants & Ethanol extract & In vitro & [2] \\
\hline \multirow[t]{4}{*}{ Fabaceae } & Leucaena leucocephala & Seeds & Aqueous extract & In vivo and in vitro & {$[12,62]$} \\
\hline & Tephrosia crassifolia & Leave and flowers & Flavonoid extract & In vitro & {$[10]$} \\
\hline & Tephrosia madrensis & $\begin{array}{l}\text { Leaves and } \\
\text { flowers }\end{array}$ & Flavonoid extract & In vitro & {$[10]$} \\
\hline & Tephrosia viridiflora & Leave and flowers & Flavonoid extract & In vitro & {$[10]$} \\
\hline Fagaceae & Quercus lusitanica & Seeds & Methanol extract & $\begin{array}{l}\text { In vitro and proteomics } \\
\text { technique }\end{array}$ & [39] \\
\hline Halymeniaceae & Cryptonemia crenulata & Whole plants & Polysaccharide extract & In vitro & {$[60]$} \\
\hline Phyllophoraceae & $\begin{array}{l}\text { Gymnogongrus } \\
\text { griffithsiae }\end{array}$ & Whole plants & Polysaccharide extract & In vitro & {$[60]$} \\
\hline Piperaceae & Piper retrofractum & Whole plants & $\begin{array}{l}\text { Dichloromethane and } \\
\text { ethanol extract }\end{array}$ & In vitro & {$[2,65]$} \\
\hline Rhizophoraceae & Rhizophora apiculata & Whole plants & Ethanol extract & In vitro & [2] \\
\hline Solieraceae & Meristiella gelidium & Whole plants & Polysaccharide extract & In vitro & [63] \\
\hline \multirow[t]{2}{*}{ Verbenaceae } & Lippia alba & Whole plants & Essential oils & In vitro & {$[23,50]$} \\
\hline & Lippia citriodora & Whole plants & Essential oils & In vitro & {$[23]$} \\
\hline Zosteraceae & Zostera marina & - & - & In vitro & [47] \\
\hline
\end{tabular}

Tephrosia crassifolia, Tephrosia madrensis and Tephrosia viridiflora

Tephrosia crassifolia, Tephrosia madrensis and Tephrosia viridiflora belong to family Fabaceae. Genus Tephrosia is an herb, undershrub or shrub, distributed mainly in tropical and subtropical regions of the world.

Three species from this family (Tephrosia crassifolia, Tephrosia madrensis and Tephrosia viridiflora) were investigated [10]. The flavonoids isolated from T. madrensis, glabranine (8) and 7-O-methyl-glabranine (9) exert strong inhibitory effects on dengue virus replication in LLC-MK2 cells. Methyl-hildgardtol A isolated from $T$. crassifolia exhibited a moderate to low inhibitory effect, while hildgargtol A from $T$. crassifolia and elongatine from T. viridiflora had no effect on viral growth.

\section{Uncaria tomentosa}

Uncaria tomentosa belongs to family Rubiaceae. It is a woody vine growing in the tropical jungles of Central and South America.

Uncaria tomentosa is a large wood vine native to the Amazon and Central American rainforests [67]. It is used widely as traditional medicine by native people of the Peruvian rainforest [68]. The antiviral activity of $U$. tomentosa was revealed by viral antigen (DENV-Ag) detection in monocytes by flow cytometry in C6/36 cells [67]. The most effective activity emerged from the alkaloidal fraction of $U$. tomentosa. The pentacyclic oxindole alkaloid-enriched fraction of $U$. tomentosa was observed as most effective at decreasing DENV-Ag detection in monocytes at concentrations of $1 \mu \mathrm{g} \mathrm{mL}^{-1}$, whereas the crude hydroethanolic extract demonstrates inhibitory activity at concentrations of $10 \mu \mathrm{g} \mathrm{mL}^{-1}$.

\section{Zostera marina}

Zostera marina belongs to family Zosteraceae. It is an aquatic plant known as eelgrass and is native to North America and Eurasia.

A compound from the temperate marine eelgrasss Zostera marina has been identified as possessing antidengue virus activity in a focus-forming unit assay in LLCMK2 cells [47]. The anti-adhesive compound p-sulfoxycinnamic acid, zosteric acid, ZA (10), derived from $Z$. marina showed a modest $\mathrm{IC}_{50}$ of approximately $2.3 \mathrm{mM}$ against DENV-2. The other compound with related 
chemistries, CF 238, showed the most activity, with $\mathrm{IC}_{50}$ values of 24, 46, 14 and $47 \mu \mathrm{M}$ against DENV-1, DENV-2, DENV-3 and DENV-4, respectively.

\section{Summary of medicinal plants tested for their anti- dengue activity}

Plants from which extracts have been prepared and tested to detect inhibition activity against DENV are listed in Table 2. This list consists of 16 plant species (from 12 families) that show high anti-dengue activity with high $\mathrm{IC}_{50}$ less than $5 \mu \mathrm{g} \mathrm{mL}^{-1}$ on four serotypes of DENV. The plants shown in Table 2 need to be studied further to identify and isolate potential bioactive compounds.

\section{Potential of plant bioactive compounds to combat dengue}

The active compounds showed a wide range of activity against DENV. The isolated products belong to various chemical classes such as sulfated polysaccharides, flavonoids, quercetin and natural chalcone compounds. The chemical structures of ten of these different phytochemicals, isolated from 11 plants, are shown in Fig. 5. The secondary metabolites of medicinal plants comprise a variety of compounds with a wide range of biological activities [68]. There are reports on medicinal plants extracts and essential oils possessing potential to new antiviral properties [41, 42]. Many plant extracts in different solvents have been reported to exhibit activity against a vector of dengue fever, Ae. Aegypti [20, 69].

\section{Conclusion and future directions}

This review has covered only 31 potential plants that could be used in the treatment of dengue and about ten isolated active phytochemicals. The available research highlights the information available for various parts and extract types of medicinal plants for the treatment of dengue. However, some of the plants that have not yet been fully explored may have a broad range of potential therapeutic applications. The development of new anti-dengue products from bioactive compounds is necessary in order to find more effective and less toxic anti-dengue drugs. Therefore, any extensive study on the potential of plants with isolated active compounds that have shown anti-dengue activity should go through additional in vitro and in vivo animal testing followed by toxicity and clinical tests. This route may reveal a promising compound to be optimized and thus be suitable for application in the production of new anti-dengue compounds. If pursued from drugs derived from medicinal plants around the continents, this work may prove valuable to the health of individuals and to nations.
Fig. 5 Structure of some potential compounds for treatment of dengue fever (DF) isolated from medicinal plants (1-10)<smiles>[R20]c1cc(O)c(C(=O)[C@H]2[C@@H](CC=C(C)C)C(C)=CC[C@H]2c2ccccc2)c(O)c1</smiles>

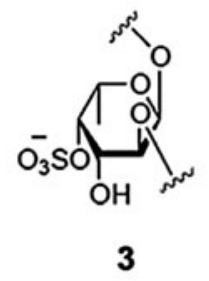

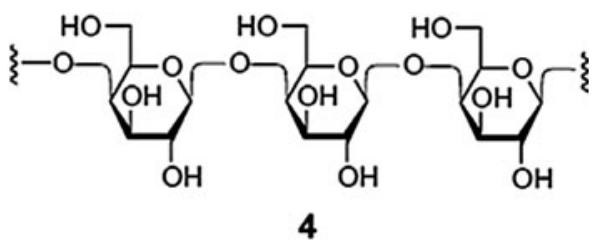<smiles>CCCCOc1c(-c2ccc(O)c(O)c2)oc2cc(O)cc(O)c2c1=O</smiles>

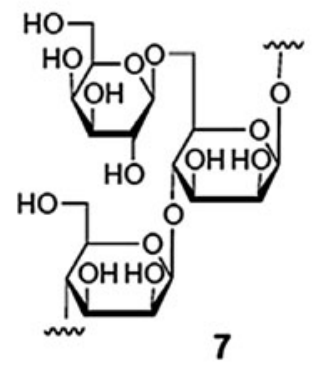<smiles>CC(C)=CCc1c(O)cc(O)c2c1O[C@H](c1ccccc1)CC2=O</smiles><smiles>COc1cc(O)c2c(c1CC=C(C)C)OC(c1ccccc1)CC2=O</smiles><smiles>O=C(O)C=Cc1cccc(OS(=O)(=O)[O-])c1</smiles> 
Moreover, such discoveries may lead to the development of highly efficient and safe anti-dengue treatments. However, to identify potential anti-dengue plants or compounds, knowledge of the mechanisms of virus infection need to be understood inorder to facilitate the search for and development of the most appropriate drugs. Further research is needed to determine how to target the most appropriate stages to prevent the spread of virus infection. Focusing on each phase in the life cycle of the virus, new compounds could prevent (1) infection of host cells, (2) the viral maturation process, (3) synthesis of viral RNA, or (4) the spread of viral particles.

Acknowledgments The authors would like to thank the World Health Organization for permission to use copyrighted material, and the Institute of Bioproduct Development, Universiti Teknologi Malaysia for financial assistance for this research work.

Open Access This article is distributed under the terms of the Creative Commons Attribution License which permits any use, distribution, and reproduction in any medium, provided the original author(s) and the source are credited.

\section{References}

1. Talarico LB, Zibetti RGM, Noseda MD, Duarte MER, Damonte EB (2007) An algal-derived DL-galactan hybrid is an efficient preventing agaent for in vitro Dengue virus infection. Planta Med 73:1464-1468

2. Klawikkan N, Nukoolkarn V, Jirakanjanakir N, Yoksan S, Wiwat C, Thirapanmethee K (2011) Effect of Thai medicinal plant extracts against Dengue virus in vitro. MU J Pharm 38(1-2): $13-18$

3. Guzman A, Isturiz RE (2010) Update on the global spread of dengue. Int J Antimicrob Agents 36S:S40-S42

4. WHO. World Health Organization (2012) Dengue and severe dengue. Fact Sheet. http://www.who.int/mediacentre/factsheets/fs $117 / \mathrm{en} /$

5. Leardkamolkarn V, Srigulpanit W, Phurimsak C, Kumkate S, Himakoun L, Sripanidkulchai B (2012) The inhibitory actions of Houttuynia cordata aqueous extract on Dengue virus and Dengue-infected cells. J Food Biochem 26:86-92. doi:10.1111/j. 1745-4514.2010.00514.x

6. Goel A, Patel DN, Lakhani KK, Agarwal SB, Agarwal A, Singla S, Agarwal R (2004) Dengue fever-a dangerous foe. J Indian Acad Clin Med 5(3):247-258

7. Tang LIC, Ling APK, Koh RY, Chye SM, Voon KGL (2012) Screening of anti-dengue activity in methanolic extracts of medicinal plants. BMC Complement Altern Med 12:3

8. Parida MM, Upadhyay C, Pandya G, Jana AM (2002) Inhibitory potential of neem (Azidarachta indica Juss) leaves on Dengue virus type-2 replication. J Ethnopharmacol 79:273-278

9. Ahmad N, Fazal H, Ayaz M, Abbasi BH, Mohammad I, Fazal L (2011) Dengue fever treatment with Carica papaya leaves extracts. Asian Pac J Trop Biomed 1:330-333. doi:10.1016/ S2221-1691(11)60055-5

10. Sanchez I, Garibay FG, Taboada J, Ruiz BH (2000) Antiviral effect of flavonoids on the Dengue virus. Phytother Res 14:89-92

11. Jain M, Ganju L, Katiyal A, Padwad Y, Mishra KP, Chanda S, Karan D, Yogendra KMS, Sawhney RC (2008) Effect of
Hippophae rhamnoides leaf extracts against Dengue virus infection in human blood-derived macrophages. Phytomedicine 15:793-799

12. Ono L, Wollinger W, Rocco IM, Coimbra TLM, Gorin PAJ, Sierakowski MR (2003) In vitro and in vivo antiviral properties of sulfated galactomannans against yellow fever virus (BeH111 strain) and dengue 1 virus (Hawaii strain). Antivir Res 60: 201-208

13. Gubler JD (2006) Dengue/dengue haemorrhagic fever: history and current status. In: Bock G, Goode J (eds) New treatment strategies for dengue and other flaviviral diseases. Wiley, Chichester (Novartis Foundation Symposium 277) pp 3-22

14. Kyle JL, Harris E (2008) Global spread and persistence of dengue. Annu Rev Microbiol 62:71-92

15. Qi RF, Zhang L, Chi CW (2008) Biological characteristics of dengue virus and potential targets for drug design. Acta Biochim Biophys Sin 40(2):91-101

16. Saleeza SNR, Rashid NY, Azirun MS (2011) Mosquitoes larval breeding habitat in urban and suburban areas, Peninsular Malaysia. World Acad Sci Eng Technol 58:569-573

17. Amarasighe A, Kuritsky JN, Letson GW, Margolis HS (2011) Dengue virus infection in Africa. Emerg Infect Dis 17(8):1349-1354

18. NaTHNaC (2009) Dengue Fever. Health Protection Agency. Natural Travel Health Network and Centre

19. CDC (2010) The Dengue Update: Dengue Outbreaks Worldwide. Centre for Disease Control and Prevention 2 (1.1)

20. Grzybowski A, Tiboni M, da Silva MAN, Chitolina RF, Passos M, Fontana JD (2011) The combined action of phytolarvacides for the control of dengue fever vector, Aedes aegypti. Braz J Pharmacogn 22:549-557 ISSN 0102-695X

21. Leyssen P, Clercq ED, Neyts J (2000) Perspectives for the treatment of infections with Flaviviridae. Clin Microbiol Rev 13(1):67-82

22. Beaute J, Vong S (2010) Cost and disease burden of dengue in Cambodia. BMC Public Health 10:521-526

23. Ocazionez RE, Meneses R, Torres FA, Stashenko E (2010) Virucidal activity of Colombian Lippia essential oils on Dengue virus replication in vitro. Mem Inst Oswaldo Cruz 105(3): 304-309

24. He JF, Luo HM, Liang WJ, Kui Z, Min K, Liu LP (2007) Epidemic situation of dengue fever in Guangdong province, China, 1990-2005. Dengue Bull 31:1-9

25. Veeraseatakul P, Wongchompoo B, Thichak S, Yananto $\mathrm{Y}$, Waneesorn J, Chutipongvivate S (2007) Circulation of dengue serotypes in five provinces of northern Thailand during 2002-2006. Dengue Bull 31:19-25

26. Singh B, Goswami A, Chawla N, Shyam S (2007) Role of helplines for dissemination of information during an outbreak of dengue fever in Delhi, India, in 2006: an experience. Dengue Bull $31: 178-181$

27. Muhammad Azami NA, Salleh SA, Neoh HM, Syed Zakaria SZ, Jamal R (2011) Dengue epidemic in Malaysia: Not a predominantly urban disease anymore. BMC Res Notes 4:216

28. Lam SK (1993) Two decades of dengue in Malaysia. J Trop Med 35(4): 195-200

29. Chen CD, Seleena B, Nazni WA, Lee HL, Masri SM, Chiang YF, Azirun MS (2006) Dengue vector surveillance in endemic areas in Kuala Lumpur city center and Selangor state, Malaysia. Dengue Bull 30:197-203

30. Ministry of Health Malaysia (2007) Health Facts 2006 Malaysia

31. Kementerian Kesihatan Malaysia (2012) Peningkatan kes kematian Denggi yang tertinggi pada tahun 2012. Kenyataan Akhbar Ketua Pengarah Kesihatan Malaysia, Putrajaya

32. Kementerian Kesihatan Malaysia (2010) Situasi semasa demam denggi dan chikugunya di Malaysia bagi minggu 1 (2010). Kenyataan Akhbar Ketua Pengarah Kesihatan Malaysia, Putrajaya 
33. Kementerian Kesihatan Malaysia (2011) Situasi semasa demam denggi dan chikugunya di Malaysia bagi minggu 52 (2010). Kenyataan Akhbar Ketua Pengarah Kesihatan Malaysia, Putrajaya

34. Kementerian Kesihatan Malaysia (2011) Situasi semasa demam denggi dan chikugunya di Malaysia bagi minggu 1 (2011). Kenyataan Akhbar Ketua Pengarah Kesihatan Malaysia, Putrajaya

35. Kementerian Kesihatan Malaysia (2012) Situasi semasa demam denggi dan chikugunya di Malaysia bagi minggu 52 (2011). Kenyataan Akhbar Ketua Pengarah Kesihatan Malaysia, Putrajaya

36. Kementerian Kesihatan Malaysia (2012) Situasi semasa demam denggi dan chikugunya di Malaysia bagi minggu 1 (2012). Kenyataan Akhbar Ketua Pengarah Kesihatan Malaysia, Putrajaya

37. Robinson MM, Zhang X (2011) The world medicines situation 2011. Traditional medicines: global situation, issues and challenges. WHO Geneva 2011. (WHO/EMP/MIE/2011.2.3)

38. Rates SMK (2001) Plants as source of drugs. Toxicon 39: 603-613

39. Muliawan SY, Kit LS, Devi S, Hashim O, Yusof R (2006) Inhibitory potential of Quercus lusitanica extract on Dengue virus type 2 replication. Southeast Asian J Trop Med Public Health 37(9):132-135

40. Zandi K, Teoh BT, Sam SS, Wong PF, Mustafa MR, Abubakar S (2011) In vitro antiviral activity of fisetin, rutin and naringenin against Dengue virus type-2. J Med Plants Res 5(23):5534-5539 (ISSN 1996-0875)

41. Newman DJ, Cragg GM, Snader KM (2003) Natural products as sources of new drugs over the period 1981-2002. J Nat Prod 66(7):1022-1037

42. Garcia CC, Talarico L, Almeida N, Colombres S, Duschatsky C, Damonte EB (2003) Virucidal activity of essential oils from aromatic plants of San Luis, Argentina. Phytother Res 17: 1073-1075

43. Jassim SAA, Naji MA (2003) Novel antiviral agents: a medicinal plants perspective. J Appl Microbiol 95:412-427

44. Pang T, Hassan H, Ramalingam S (1988) Demam denggi dan demam denggi berdarah. Dewan Bahasa dan Pustaka, Kuala Lumpur

45. Suaya JA, Shephard DS, Siqueira JB, Martelli CT, Lum LCS, Tan LH, Kongsin S, Jiamton S, Garrido F, Montoya R, Armien B, Huy R, Castillo L, Caram M, Sah BK, Sughayyar R, Tyo KR, Halstead SB (2009) Cost of dengue cases in eight countries in the Americas and Asia: a prospective study. Am J Trop Med Hyg 80(5):846-855

46. Muhamad M, Kee LY, Rahman NA, Yusof R (2010) Antiviral actions of flavonoid-derived compounds on Dengue virus type-2. Int J Biol Sci 6(3):294-302

47. Rees CR, Costin JM, Fink RC, McMichael M, Fontaine KA, Isern S, Michael SF (2008) In vitro inhibition of dengue virus entry by $p$-sulfoxy-cinnamic acid and structurally related combinatorial chemistries. Antivir Res 80:135-142

48. Solomon T, Mallewa M (2001) Dengue and other emerging Flaviviruses. J Infect 42:104-115

49. WHO World Health Organization (2008) Traditional medicine. Fact Sheet. http://www.who.int/mediacentre/factsheets/fs134/en/

50. Meneses R, Ocazionez RE, Martinez JR, Stashenko EE (2009) Inhibitory effect of essential oils obtained from plants grown in Colombia on yellow fever virus replication in vitro. Ann Clin Microbiol Antimicrob 8:8

51. Betancur-Galvis LA, Saez J, Granados H, Slazar A, Ossa JE (1999) Antitumor and antiviral activity of Colombian medicinal plant extracts. Mem Inst Oswaldo Cruz 94(4):531-535
52. Kudi AC, Myint SH (1999) Antiviral activity of some Nigerian medicinal plants extracts. J Ethnopharmacol 68:289-294

53. Philippine Medicinal Plants (2011) Gatas-gatas. http://www. stuartxchange.org/GatasGatas.html

54. The Cure Library (2007) Dengue fever cure using tawa-tawa aka gatas-gatas weed. http://www.curelibrary.com/blog/2007/04/

55. About Health (2011) Dengue fever medicine. Available from URL: http://abouthealt-h.com/dengue-fever-medicine

56. Healthy Lifestyle (2010) Guava leaf, prevent Dengue Haemorrhage. http://www.secondlifeblogs.info/guava-leaf-prevent-denguehaemorrhage.html

57. Jiang WL, Luo XL, Kuang SJ (2005) Effects of Alternanthera philoxeroides Griseb against dengue virus in vitro. J First Mil Med Univ 25(4):454-456

58. Kiat TS, Pippen R, Yusof R, Ibrahim H, Khalid N, Rahman NA (2006) Inhibitory activity of cyclohexenyl chalcone derivatives and flavonoids of fingerroot, Boesenbergia rotunda (L.), towards dengue-2 virus NS3 protease. Bioorg Med Chem Lett 16: $3337-3340$

59. Hidari KIPJ, Takahashi N, Arihara M, Nagaoka M, Morita K, Suzuki T (2008) Structure and anti-Dengue virus activity of sulfated polysaccharide from marine alga. Biochem Biophys Res Commun 376:91-95

60. Talarico LB, Zibetti RGM, Noseda MD, Duarte MER, Damonte EB, Faria PCS, Pujol CA (2005) The antiviral activity of sulfated polysaccharides against Dengue virus is dependenton virus serotype and host cells. Antivir Res 66:103-110

61. Pujol CA, Estevez JM, Carlucci MJ, Ciancia M, Cerezo AS, Damonte EB (2002) Novel DL-galactan hybrids from the red seaweed Gymnogongrus torulosus are potent inhibitors of herpes simplex virus and dengue virus. Antivir Chem Chemother 13(2): 83-89

62. Srivastava M, Kapoor VP (2005) Seed galactomannans: an overview. Chem Biodivers 2:295-317

63. SF Tischer PC, Talarico LB, Noseda MD, Guimaraes SMPB, Damonte EB, Duarte MER (2006) Chemical structure and antiviral activity of carragenans from Meristiella gelidium against herpes simplex and dengue virus. Carbohyd Polym 63:459-465

64. Mohan L, Amberkar MV, Kumari M (2011) Ocimum sanctum Linn (Tulsi)—an overview. Int J Pharm Sci Rev Res 7(1):51-53 (ISSN 0976-044X)

65. Chansang U, Zahiri NS, Bansiddhi J, Boonruad T, Thongsrirak P, Mingmuang J, Benjapong N, Mulla MS (2005) Mosquito larvacidal activity of aqueous extracts of long pepper (Piper retrofractum Vahl) from Thailand. J Vector Ecol 30(2):195-200

66. Pink Roses (2011) Guava leaf extract potential cure dengue fever. http://pinkroses.info/guava-leaf-extract-potential-cure-dengue-fever

67. Reis SRIN, Valente LMM, Sampaio AL, Siani AC, Gandini M, Azeredo EL, D'Avila LA, Mazzei JL, Henriques MGM, Kubelka CF (2008) Immunomodulating and antiviral activities of Uncaria tomentosa on human monocytes infected with Dengue Virus-2. Int Immunopharmacol 8:468-476

68. Vijayan P, Ragu C, Ashok G, Dhanaraj SA, Surej B (2004) Antiviral activity of medicinal plants of Nilgiris. Indian $\mathrm{J}$ Med Res 120:24-29

69. Choochote W, Tuetun B, Kanjanapothi D, Rattanachanpicai E, Chaitong U, Chaiwong P, Jitpakdi A, Tippawangkosol P, Riyong D, Pitasawat B (2004) Potential of crude seed extract of celery, Apium graveolens L., against the mosquito Aedes aegypti (L.) (Diptera: Culicidae). J Vector Ecol 29(2):340-346 